\title{
The Farmers Union and the 1948 Henry Wallace Campaign
}

\section{William C. PRatT}

THE 1948 HENRY WALLACE CAMPAIGN was a watershed in the history of the American left. Despite high hopes, this third party candidacy made a dismal showing at the ballot box. None of its backers, including the candidate, had believed that it actually would elect the next president, but they had expected to solidify the liberal-left elements in the country and build an electoral base for subsequent campaigns. Instead, the campaign resulted in the discrediting of left-wing third party efforts, the stigmatization of popular front politics, and the increased hegemony of anti-Communists within the ranks of American liberalism. The 1948 Wallace campaign was one of the left's worst setbacks in recent American history. This outcome often is explained by increasing Cold War tensions, marked especially by the 1948 Czech and Berlin crises; the close identification between the Wallace effort and the Communist party; the shrewd campaign strategy of the Truman campaign; and the bungling of the Wallace campaign itself. ${ }^{1}$ Whatever the explanation, Wallace's declining political base from early 1947 through the 1948 campaign played a major role in his ultimate poor showing in the election. An exploration of the response of one liberal organization-the National Farmers Union (NFU)-to Wallace's 1948 effort should help us better understand the challenge this episode made to mainstream American liberalism,

1. The 1948 Wallace campaign is treated in Karl M. Schmidt, Henry A. Wallace: Quixotic Crusade 1948 (Syracuse, NY, 1960); Curtis D. MacDougall, Gideon's Army (New York, 1965); Norman D. Markowitz, The Rise and Fall of The People's Century: Henry A. Wallace and American Liberalism, 1941-1948 (New York, 1973); Allen Yarnell, Democrats and Progressives: The 1948 Presidential Election as a Test of Postwar Liberalism (Berkeley and Los Angeles, 1974); Richard J. Walton, Henry Wallace, Harry Truman, and the Cold War (New York, 1976). 
and the difficulties that the third party movement had in recruiting among liberal groups.

JAMES G. PATTON AND THE NFU were an important team on the playing fields of American liberalism in the 1940s. During World War II Patton emerged as one of the chief spokesmen for progressive reform and was identified with the left wing of the New Deal coalition. His organization was the nation's only liberal farm group, and in some eyes he may have been seen as the agricultural equivalent of Walter Reuther. It seemed that every liberal effort wanted Patton's backing in the war years and in the postwar era. ${ }^{2}$ While Patton was in the spotlight, he shared power with two other key Farmers Union leaders: M. W. (Bill) Thatcher, general manager of the Grain Terminal Association (GTA), which was the organization's largest cooperative enterprise, and Glenn J. Talbott, president of the North Dakota Farmers Union, which was the organization's largest state affiliate. Thatcher had been one of the builders of the NFU in the Upper Midwest and headed up the Union's grain coop empire in the region. A forceful personality, he exerted a great deal of influence within the organization as a consequence of his political skills (both within and outside the Union), GTA's financial resources, and its army of fieldmen. GTA checks for educational funds were an important source of income for state unions in the region. Talbott, on the other hand, may have been the single most influential figure in the Farmers Union. North Dakota's large membership provided him with a base, and he served as chairman of the NFU's executive committee. Patton was national president, but he clearly shared power with both Thatcher and the North Dakota leader. ${ }^{3}$

The Farmers Union had been one of the nation's most important farm organizations since its founding in 1902. It claimed

2. For Patton, see Alonzo L. Hamby, Beyond the New Deal: Harry S. Truman and American Liberalism (New York and London, 1973); Charles Henry Livermore, "James G. Patton: Nineteenth-Century Populist, Twentieth-Century Organizer, Twenty-First Century Visionary" (Ph.D. diss., University of Denver, 1976).

3. John A. Crampton, The National Farmers Union: Ideology of a Pressure Group (Lincoln, NE, 1965); and William C. Pratt, "Glenn J. Talbott, the Farmers Union and American Liberalism after World War II," North Dakota History 55 (Winter 1988), 3-13. 
to be a descendant of earlier agrarian movements, and one observer has characterized it as "Populism-Up-to-Date." Though it lagged behind the Farm Bureau and the Grange in membership, the Farmers Union had a major presence in the Upper Midwest and on the Plains. ${ }^{4}$ Patton, Thatcher, and Talbott were part of the New Deal faction that had taken over the organization in the late 1930s and eventually elected Patton as its president in 1940. Though usually close to Roosevelt, the NFU leader was not reluctant to criticize Administration policy from time to time. ${ }^{5}$ Patton's public posture during and immediately after the war placed him among popular front liberals who were willing to work with Communists in a domestic political alliance against fascism abroad and at home. Then, it was not unusual for liberals and Communists to work together on specific tasks. A popular front or left-liberal coalition emerged within elements of the Democratic party, several CIO unions, some civil rights organizations, and other groups, and in many cases there was little public stigma about it at the time. ${ }^{6}$ But in the postwar era, these wartime associations came back to haunt many of those who had been involved in them.

A close relationship between the Farmers Union and Henry Wallace had existed since the late 1930s. These ties had been strengthened as a result of a "sweetheart arrangement" between the Department of Agriculture's Farm Security Administration (FSA) and the FU cooperatives. FSA loans to farmers in the Upper Midwest often included funds to buy stock in local grain cooperatives, which, in turn, affiliated with the Thatchermanaged GTA. C. B. "Beanie" Baldwin, a key Wallace aide, ad-

4. For the Farmers Union, see William P. Tucker, "Populism Up-to-Date: The Story of the Farmers Union," Agricultural History 21 (October 1947), 198208; and Crampton, National Farmers Union.

5. Crampton, National Farmers Union, 139-44, 222-24; Lowell K. Dyson, Red Harvest: The Communist Party and American Farmers (Lincoln, NE, 1982); "Farm Union Head Charges FDR Deserted 'Little Man,'" Rocky Mountain News, 29 September 1943, clipping in Talbott Family Papers, University of North Dakota, Grand Forks, North Dakota.

6. For discussion of the popular front in the 1940s, see Norman Markowitz, "A View from the Left: From the Popular Front to Cold War Liberalism," in Robert Griffith and Athan Theoharis, eds., The Specter: Original Essays on the Cold War and the Origins of McCarthyism (New York, 1974), 90-114, 305-10. The term popular front has been applied by historians to this leftliberal alliance after the fact; it was not used by its participants in the 1940s. 
ministered the FSA during the war and had close ties with both Thatcher and Patton. He recruited Patton for the National Citizens Political Action Committee (NCPAC), which backed FDR and other liberal candidates in 1944, and he was an intimate friend of the NFU president well into the postwar period. ${ }^{7}$

The connection between Wallace and the Farmers Union was not based solely on administration farm policy. Like the $\mathrm{CIO}$, the NFU took positions on a variety of issues not directly related to its members' economic interests. Patton and his organization emerged as strong proponents of civil rights, including the abolition of the poll tax; they also called for an alliance between farmers and labor; the creation of jobs in the postwar era; and, in the rhetoric of the wartime popular front, the defeat of fascism abroad and at home. Patton and other FU figures were disappointed when Wallace, who shared similar views on these issues, was dropped from the ticket in 1944, and later they lobbied hard for his confirmation as secretary of commerce in Roosevelt's last cabinet. Even before FDR's death, Wallace was seen by many in liberal circles, including the Farmers Union, as the spokesman for the left wing of the New Deal, and he clearly emerged with that mantle in the immediate postwar era. ${ }^{8}$

After FDR's death, the NFU, like many other New Deal supporters, initially was pleased with Truman as president. It approved of his choice of Clinton P. Anderson as secretary of agriculture, and Patton told National Union Farmer readers in its October 1945 issue, "we must rally behind President Truman!" He went on to say, "The President has outlined to Congress a progressive, enlightened program for the United States which

7. For FSA-NFU relationship, see Sidney Baldwin, Poverty and Politics: The Rise and Decline of the Farm Security Administration (Chapel Hill, NC, 1968), 299-301; and Ross B. Talbot, "The North Dakota Farmers Union and North Dakota Politics," Western Political Quarterly 10 (December 1957), 87677. For Patton-Baldwin ties, see "PCA and Progressive PartyCorrespondence 1944-1951," box 23, C. B. Baldwin Papers, University of lowa, lowa City, lowa.

8. Hamby, Beyond the New Deal; Markowitz, Rise and Fall of The People's Century. Emil Loriks, a key Farmers Union figure in South Dakota and a former NFU secretary-treasurer, wrote to Patton, "Wallace symbolizes the things we stand for. We supported him with all our might at the last Nat'l Democratic Convention in Chicago (you and I were both there)[.]" Loriks to Patton, 18 January 1948, box 10, Emil Loriks Papers, American State Bank, Oldham, South Dakota. 
coincides with the National Farmers Union program in most respects. ${ }^{\prime 9}$ Within two months, however, this tone changed. The NFU blasted Anderson's choice to head the FSA. According to Patton, "The appointment by Secretary Anderson of Dillard Lasseter to head the Farm Security Administration is a bitter betrayal of small farmers." ${ }^{10}$ As the major backer of the FSA, the NFU assumed what amounted to a proprietary interest in it.

The liberal honeymoon with Truman ended quickly. By early 1946 New Dealers and popular fronters became disenchanted with "the man from Independence." Administration actions in both foreign affairs and on the home front, including Truman's "get tough with the Russians" talk, Clinton Anderson's conduct as secretary of agriculture, and Truman's threat to draft striking railroad workers, alienated a formidable number of national figures. Patton and other NFU spokesmen sought Anderson's removal, attacked the striker draft proposal as "naked, open fascism," and joined ranks with other public critics of Truman's foreign policy.11

Even before Truman fired Wallace from his cabinet in September 1946, left-liberal elements were at work attempting to rebuild a liberal New Deal coalition. Beanie Baldwin, Elmer Benson, former Farmer-Labor governor of Minnesota and now chairman of NCPAC, and others sought to regroup alienated labor leaders, civil rights spokesmen, and others who had been mobilized in the Depression and war years. Among those deeply interested in such efforts was the Communist party, which had played a part in earlier reform efforts. ${ }^{12}$ Many former New Dealers were alienated by Truman's policies and were not afraid to work with Communists and others close to them in an attempt to form a left-liberal alternative to the Administration. Baldwin

9. National Union Farmer, October 1945. The NFU's relations with the Truman Administration in regard to farm policy are treated in Allen J. Matusow, Farm Policies and Politics in the Truman Years (New York, 1970).

10. Gardner Jackson, "Anderson Gives FSA to Outsider," National Union Farmer, 15 December 1945.

11. National Union Farmer, 1 June 1946; Hamby, Beyond the New Deal; Markowitz, Rise and Fall of The People's Century; Mary Sperling McAuliffe, Crisis on the Left: Cold War Politics and American Liberals, 1947-1954 (Amherst, MA, 1978); Steven M. Gillon, Politics and Vision: The ADA and American Liberalism, 1947-1985 (New York and Oxford, 1987).

12. For the Communist party in the postwar era, see Joseph R. Starobin, American Communism in Crisis, 1943-1957 (Cambridge, MA, 1972). 
and others organized a Conference for Progressives to meet in Chicago in September. Among the individual sponsors of the meeting was Patton. The week prior to the conference, Truman fired Wallace from his cabinet for criticizing Administration foreign policy, setting the stage for a showdown between Truman and left-liberal opponents of the Administration. ${ }^{13}$

The Chicago conference, "one of the widest and most representative assemblies of liberals ever brought together," attracted a great deal of attention. Patton, who made a major speech, Thatcher, and presidents of the Farmers Union in Montana, Iowa, Minnesota, Oregon, New York, and the Eastern Division, which included Pennsylvania and New Jersey, were joined by Philip Murray, A. F. Whitney, Clark Foreman, Walter White, Claude Pepper, Henry Morganthau, and other prominent liberal figures. ${ }^{14}$ On the surface, it was an impressive show of force. Behind the scenes, however, $\mathrm{CIO}$ president Philip Murray refused to join the ranks, and the Conference for Progressives failed to strengthen the popular front cause. The CIO leadership balked at working with Communists, and a new liberal formation, the anti-Communist Americans for Democratic Action (ADA), emerged in early 1947. In December 1946 Baldwin and his allies had already organized the Progressive Citizens of America (PCA), which subsequently served as the base for the 1948 Progressive party. ${ }^{15}$ Overall, however, they failed to transfer the widespread liberal antipathy toward Truman into the vehicle of a viable third party.

Outwardly, Patton and other key Farmers Union figures seemed in the Wallace camp. Patton, at Baldwin's invitation, spoke out against Truman's policy on Greece and Turkey in a radio broadcast, and the National Union Farmer and other FU papers often gave Wallace very favorable coverage. Patton seemed particularly sympathetic in extemporaneous remarks to Iowa FU activists in March 1947. According to a local newspaper account, the NFU leader " called for the formation of a new political

13. See sources cited in note 11 .

14. Eastern Union Farmer, November 1946; Hamby, Beyond the New Deal, 154. Talbott did not attend, but he sent a representative.

15. Bert Cochran, Labor and Communism: The Conflict that Shaped American Unions (Princeton, NJ, 1979), 265-68; Hamby, Beyond the New Deal, 15564; Gillon, Politics and Vision, 12-22. 
movement either on the basis of new or old political parties but under the leadership of Henry Wallace or someone like him." The North Dakota union sponsored a Wallace speech in Bismarck later that spring and gave his efforts a great deal of publicity. ${ }^{16}$

Baldwin and Wallace courted the Farmers Union throughout 1947. In a New Republic article, the former vice-president heaped praise upon the NFU leadership. He singled out the North Dakota union for special attention, asserting at one point, "the farmers of North Dakota are moving toward a new agrarian radicalism."17 Baldwin was in frequent contact with Patton throughout the year. Nothing in the written record suggests that Patton ever encouraged the third party approach to Wallace's aide, but the tone was always cordial and friendly. To many observers it probably looked like the Farmers Union was in the Wallace camp to stay.

After the third party decision was announced on December 29, 1947, many Wallace backers assumed that Patton ultimately would join in. In early February 1948, the steering committee of the Progressive campaign met in Chicago. One of the topics of discussion was Wallace's running mate. Idaho Senator Glen Taylor already had been asked, but had not yet decided. The minutes of this meeting reveal that Patton was the group's third choice and that both Thatcher and Talbott also were mentioned as possibilities. ${ }^{18}$ Yet by this time Patton and Thatcher already had told intimates that they were opposed to the third party campaign, and Talbott's board had decided not to back the

16. Baldwin to Patton, 9 and 10 April 1947; Patton to Baldwin, 10 April 1947; and Mason City Globe, 21 March 1947, James G. Patton Papers, University of Colorado, Boulder, Colorado; North Dakota Union Farmer, 16 June 1947. Soon after his radio broadcast, Patton wrote to a friend, "The Wallace fight is really something[,] isn't it? Henry is, in my opinion[,] doing a damned good job of stirring things up. All to the good." Patton to Jim Maddox, 18 April 1947, Patton Papers. For NFU opposition to the Truman Doctrine, see National Union Farmer, 1 April 1947.

17. Henry A. Wallace, "Report on the Farmers," New Republic 116 (30 June 1947), 12-13.

18. Minutes of Wallace Steering Committee, 4-5 February 1948, Baldwin Papers. Patton ranked behind Senator Glen Taylor of Idaho and Albert Fitzgerald, president of the United Electrical Workers (CIO). Although Taylor had been asked on January 9, 1948, he did not accept until mid-February. MacDougall, Gideon's Army, 306-10. 
Wallace cause. ${ }^{19}$ In 1948 the Farmers Union inner circle became reconciled to and then supportive of the Truman Administration, ultimately celebrating the Truman victory as its own. What happened between mid-1947 and the 1948 campaign?

THE SINGLE BIGGEST ISSUE was that of the third party. Patton, Thatcher, and Talbott were all disenchanted with Truman and were quite willing to encourage Wallace within the Democratic party, but each of them had expressed grave reservations about third party efforts in 1948. In August 1947, Patton told Baldwin, "Beanny[,] I see no hope of accomplishing anything-NOW - in a 3rd Party unless we want to bring Fascism faster . . . but I feel we would have it a long time and the people of the world would be more victimized by our military corporatism than they are now. It seems to me that all possible effort should be made to elect a Congress-even if an SOB is President." The farm leader also indicated that he was considering running for the U.S. Senate in Colorado in 1948 and that public support for Wallace would hurt him politically. Despite that consideration, he momentarily agreed to sign a pro-Wallace statement that Baldwin had sent. Two days later, however, Patton changed his mind and withdrew his signature..$^{20}$ Apparently he was concerned that this public gesture might be interpreted as support for a third party; he also feared the harm it might do him politically and perhaps the NFU as well.

Once Wallace announced his third party candidacy in late 1947, Patton publicly stated that the Farmers Union would not "commit itself on any candidate in this year's three-corner race for president." Privately, he told Emil Loriks, "I have in no way lost my feeling for the things he [Wallace] stands for. Unless some radical change comes about, I will cast my personal vote for him as President." But he also told Aubrey Williams that he didn't think that state FU presidents should "endorse presidential candidates at this time." Two months later Charles Brannan, a close friend and then assistant secretary of agriculture, ex-

19. Patton to Aubrey Williams, 2 January 1948, Patton Papers; Hubert $H$. Humphrey to Byron Allen, 15 January 1948, Hubert H. Humphrey Papers, Minnesota Historical Society, St. Paul, Minnesota; Talbott to V. C. Moore, 23 January 1948, Talbott Family Papers.

20. Patton to Baldwin, 31 August, 2 September 1947, Baldwin Papers. 
pressed concern over a report he had heard that Patton was about to endorse Wallace. The farm leader immediately sent Brannan a telegram denying the story. ${ }^{21}$

Yet while he urged an uncommitted stance, Patton continued to offer advice and sought to influence both Truman and Wallace. He met with Truman, successfully lobbied for Brannan as Anderson's successor, and seemingly was on good terms with the president despite his earlier criticism. Brannan's appointment, followed by Patton's inclusion on a U.S. delegation to western Europe, helped cement his relations with Truman. ${ }^{22}$ After the Democratic convention, the president asked the Eightieth Congress for action on a wide range of new proposals. Patton immediately telegraphed, "The Farmers Union is 100 percent behind your recommendations." Prior to this message, Truman had invited Patton to the White House "to discuss Long Range Agricultural programs." Patton's memorandum of this meeting reports that the two men discussed a range of topics, and a subsequent letter from Patton to Williams demonstrates that Truman had persuaded him of his good intentions in the realm of foreign policy. ${ }^{23}$ Patton followed up the visit with a letter to Truman detailing suggestions for an October visit between the president and Stalin. He noted the political potential of such an initiative, saying, "I believe that it would be dramatic enough so that it would catch both Republicans and the Wallaceites flat-footed, and it would come

21. National Union Farmer, January 1948; Patton to Loriks, 22 January 1948, Loriks Papers; Patton to Williams, 2 January 1948; Brannan to Patton, 7 March 1948; Patton to Brannan, 11 March 1948, Patton Papers.

22. "FU Praises Selection of Brannan," National Union Farmer, June 1948. Matusow, Farm Policies and Politics in the Truman Years, 171-72, believes that Truman picked Brannan "partly to secure the support of the Farmers Union."

23. Patton to Truman, 27 July 1948, Harry S. Truman Papers, Harry S. Truman Library, Independence, Missouri; Patton to National Farmers Union Executive Committee and Officers, 22 July 1948, Talbott Family Papers. In his letter to Williams, Patton noted, "Well-I feel as though there is some hope for Truman-if we can find some way for him to pull himself out of this damnable international mess-he had permitted the military-Catholic-big business crowd to project him into. He is thinking seriously about it NOW. When I saw him this morning he seemed to be sure the Russ thing would not be war and that [the] U.S. would need to give some on the Berlin thing." Patton to Williams, 21 July 1948, Aubrey Williams Papers, Franklin D. Roosevelt Library, Hyde Park, New York. 
late enough in the campaign so that it would be almost impossible for them to stir up any defense or propaganda." ${ }^{24}$ Never supportive of a third party effort in 1948, Patton seemingly was in Truman's corner by late summer of that year.

Yet the farm leader also attempted to influence the Wallace campaign from the inside. His administrative assistant, Lee Fryer, was a Wallace supporter, and Patton "loaned" him to the Progressives for a Chicago meeting in April 1948. Upon returning to NFU headquarters in Denver, Fryer wrote a detailed letter of suggestions to Rexford Tugwell, then an adviser to the Wallace campaign. Much of it related to broadening the base of the Wallace movement and reducing the influence (or at least the visibility) of Communists in the organization. ${ }^{25}$ Later, in July, Fryer elaborated on the same themes in a letter to Louis Adamic, another Wallace backer. The NFU functionary premised his recommendations on a Wallace break with the Communist party, which he argued was essential and should occur prior to the Progressive party convention. Included among Fryer's proposals was the suggestion of a total campaign organization shakeup: "He [Wallace] cleans house in his national organization, removing Beanie and all the others, who seem to form the narrow ideological group. He brings Glen Taylor into this operation as a counsellor." Fryer claimed that this "purge" could be carried out without "red-baiting" or damage to the campaign. ${ }^{26}$

How much was the sorcerer's apprentice speaking for himself and how much was he speaking for the sorcerer? At the time, Adamic and perhaps others believed that Fryer probably was representing Patton's views as well. ${ }^{27}$ Though the farm leader

24. Patton to Truman, 23 July 1948, Talbott Family Papers.

25. C. B. Baldwin to James Patton, 30 April 1948, Patton Papers; Fryer to Tugwell, 22 April 1948, Progressive Party Papers. Fryer said at one point, "[The] American people, loaded as they are with propaganda, will not give mass support or mass votes to a Communist-led organization. Ministers, PTA leaders, Farmers Union leaders, and local progressive people of prestige cannot come in in large enough numbers while the present situation exists."

26. Fryer to Adamic, 10 July [1948], Wallace Papers. Fryer claimed, "I know at least 10 untapped people of surpassing competence, not now in the Wallace movement, who would help put over a clean organization in the third party. The lack of available competent personnel need not be a serious problem."

27. Adamic forwarded a copy of Fryer's letter to Wallace, saying, “I think this will interest you. You know Lee Fryer. I'm sure that Jim Patton feels pretty much the same." Adamic to Wallace, [ca. 12 July 1948], Wallace Papers. 
was moving toward Truman, this shift was not public, and his private remarks to some seemed sympathetic to Wallace. A West Coast Progressive, Nina Dexter, had called Patton in early July. According to her account, "although very much for Wallace," he was concerned about the campaign organization. ${ }^{28} \mathrm{~A}$ few days prior to Fryer's letter to Adamic, Patton himself had sketched out a similar scheme to a correspondent in regard to Wallace severing his ties with the Communists. He told A. W. Ricker, the retired editor of the Farmers Union Herald,

If the Democrats run Truman, then I think that there should be a major effort made for the Americans for Democratic Action group and the Wallace group to get together behind Wallace on a long-time Third Party proposition. Certainly the only way that this can be done effectively is for Wallace to read the brethren [Communists] out, and at the same time begin to discuss in philosophical terms the long range thing beyond the November election. ${ }^{29}$

Patton's stance changed by the end of July, however. Truman had been nominated, the Progressive convention had been held, and the NFU leader had visited the White House. Both Aubrey Williams, president of the Alabama FU, and Ricker wrote to him of their enthusiasm for the third party platform and Wallace's acceptance speech. ${ }^{30}$ By then, Patton was quite

28. Dexter to Jess Gitt, 30 August 1948, Jess Gitt Papers, Pennsylvania State University, University Park, Pennsylvania. Emphasis added. In an earlier letter, Dexter wrote, "In talking to Jim Patton the other day on the telephone he told me that he had talked with Beanie about many issues in the State Committees of certain people who wanted everything to be either black or white and would not compromise, but Jim did not approve of Wallace redbaiting and he also said that many of these people in the State Committees, as well as those (maybe) in the New York office, none of which he mentioned in particular, did not necessarily belong to the Communist Party in any way, but that they were too black and white in their wishes to do things and did not have enough cooperation for people who differed with each other. Jim told me that Wallace and Beanie were old friends of his and it was very hard for him to criticize anything because he believed so much in what we are fighting for in this movement." Dexter to Adamic, 8 July 1948, Progressive Party Papers.

29. Patton to Ricker, 6 July 1948, Patton Papers.

30. Williams to Patton, 26 July 1948; Ricker to Patton, 26 July 1948, Patton Papers. Williams, however, controlled his enthusiasm and did not back Wallace at any time during the 1948 campaign. See Aubrey Williams to John Coe, 21 April 1959, Williams Papers. 
critical of the Wallace effort and, in a letter to Ricker, criticized its farm program.

For an outfit that has a reputation for being left-wing and progressive, they certainly have toned their stuff down. It is ridiculous for them to attempt to cut and hedge with the thought in mind that they can influence the American economic and political scene by such procedure. Had they really been progressive, they would have struck out hard, with biting programs which would have the effect of doing a fundamental job of redistributing income in this country. ${ }^{31}$

Patton's behavior in the 1948 campaign suggests a desire on his part to run with both the fox and the hounds. Wanting to be considered a radical privately, he almost always assumed a more moderate posture publicly. In 1948 he himself had testified in favor of the Hope-Aiken bill, which provided for flexible price supports by 1950 , while in private he criticized the Wallace effort for not advocating a more radical farm program..$^{32}$ By the early fall the NFU head was pretty well committed to Truman, though pessimistic about his chances for election. ${ }^{33}$ Privately, however, he still may have hoped for the eventual formation of a left-wing movement "untainted" with Communist involvement.

The other Farmers Union notables also discretely avoided committing themselves to the Wallace crusade. Thatcher, more than the others, was indebted to Wallace and Baldwin. In October 1946 he invited the former vice-president to speak at the dedication of the new GTA building and asserted, "There would be no great GTA and these fine buildings except for Franklin D. Roosevelt and Henry A. Wallace." Less than one year later, how-

31. Patton to Ricker, 29 July 1948, Patton Papers.

32. Matusow, Farm Policies and Politics in the Truman Years, 141, writes, "Even James Patton was seduced by the sliding scale and temporarily abandoned his campaign for high, rigid supports." Patton later said, "That [supporting Hope-Aiken] was one of the big mistakes I made." James G. Patton, interview with author, Omaha, NE, 12 March 1973. See also Thomas G. Hall, "The Aiken Bill, Price Supports and the Wheat Farmer in 1948," North Dakota History 39 (Winter 1972), 13-22, 47.

33. Twenty-five years later, Patton recalled that he had told Truman something like "my contribution in 1948 is to try to convince my compatriots in the Farmers Union that they shouldn't endorse Wallace." Patton, interview with author. 
ever, when talk of a third party bolt was in the air, Thatcher cautioned his old friend against this drastic step. "I hold no brief for Mr. Truman nor am I anxious to see him return to the White House," he wrote in July 1947, but he felt that a third party effort would "deliver Dewey, Taft, or Vandenburg into the White House, and you would be forever blamed for it." The GTA head counseled Wallace to wait until 1952. When the third party bid was announced, Thatcher quickly assured Hubert Humphrey that he would not support it. ${ }^{34}$

Talbott, a less visionary figure than Patton, seemingly was more tempted by the Progressive cause than his two Farmers Union associates. ${ }^{35}$ Earlier, he and the North Dakota FU had been strong backers of Wallace. Though indicating his disapproval of a third party in October 1947, he may have given the matter some additional consideration in the new year. The North Dakota FU had organized a political arm, the Farmers Union Progressive Alliance (FUPA), to mobilize its forces against conservative opponents in state politics. Its director was Quentin Burdick, the union's counsel and a strong Wallace advocate. He and others hoped that the Alliance would endorse the former vice-president's bid.

Talbott reported that all of the organization's directors were "strong Henry Wallace supporters," but they declined to endorse him. This decision, according to the FU leader, "was taken after hours of discussion" because of the local necessity of working through the Republican party. He "had discussed this matter in detail with Beanie Baldwin and he and Henry were in thorough agreement on this position." Still, Talbott himself was thought by some to be in Wallace's camp. Fred Stover, the Iowa FU president and a strong third party man, recalls that the North Dakota farm leader told Wallace at a private Minneapolis meeting in early 1948 that he would publicly endorse him, but had to wait until after the Republican primary. No such endorsement ever was made, however. But Quentin Burdick was selected later as a North Dakota delegate to the Wallace convention. Talbott did

34. Thatcher to Wallace, 21 October 1946, 16 July 1947, Henry A. Wallace Papers, University of Iowa, Iowa City; Hubert H. Humphrey to Byron Allen, 15 January 1948, box 53, Humphrey Papers.

35. For this and the following paragraph, see Pratt, "Glenn J. Talbott, the Farmers Union, and American Liberalism After World War II." 
not require him to take vacation time for his absence and arranged for the FUPA to pay his travel expenses.

Although the Wallace crusade did not receive open support from the NFU's "Big Three," key union people at the state and local level often were found in the Progressive camp. In North Dakota, Minnesota, Iowa, Montana, and New Jersey, for example, the third party effort enjoyed strong support in some FU circles. Talbott claimed all his board members were "strong Henry Wallace supporters," and one of them-Henry Williams-was on the executive committee of the state's Progressive party. ${ }^{36}$ Martin Lane, president of South Dakota's largest county organization, was very active in the initial Wallace organizing effort in his state. ${ }^{37}$ In Montana, Chet Kinsey resigned as a Farmers Union organizer when he assumed the secretaryship of the third party effort there. The vice-president of the state party also was an FU member. ${ }^{38}$ In Minnesota the Farmers Union leadership was identified with the Wallace cause, as was Benny Brandt, a GTA board member from the northwestern part of the state. ${ }^{39}$ Iowa union president Fred Stover immediately endorsed Wallace's candidacy, served as temporary chairman of the state organization, and made the nominating speech for the candidate at the Philadelphia convention. Other FU members in Iowa also were active in the campaign, including Clarence

36. Talbott to V. C. Moore, 23 January 1948, Talbott Family Papers; Bismarck Tribune, 26 July 1948. Five of the seven members on the North Dakota Progressive party's executive committee belonged to the Farmers Union. In addition, two of the state's four Wallace electors were FU members. The Farmers Union affiliation of these individuals was not mentioned in the newspaper account, however.

37. Emil Loriks to Elmer Benson, 2 February 1948, box 10, Loriks Papers. It should be noted, however, that the Wallace effort was much weaker in South Dakota than in North Dakota and Minnesota, and "South Dakota was the only state" that did not send a delegate to the national convention. MacDougall, Gideon's Army, 607.

38. "Communist Infiltration in the National Farmers Educational and Co-operative Union of America, 22 July 1949, FBI File 100-45768-81. Late in the campaign state FU president Donald Chapman was photographed with Wallace when he made a brief stop in Great Falls. Great Falls Tribune, 11 October 1948. Chapman, however, did not support the Progressive standard bearer. Harold Ridenour, telephone interview with author, 21 February 1988.

39. Phil Clark, "Administration Change Most Important Action of Minnesota Farmers Union Convention at St. Cloud," Willmar Daily Tribune, 14 November 1949; Elmer Benson to Emil Loriks, 10 February 1948, box 10, Emil Loriks Papers. 
Biederman, who was the Progressive party's gubernatorial candidate. ${ }^{40}$ The FU's Eastern Division, which included New Jersey and Pennsylvania, officially endorsed Wallace, and many of its New Jersey members were strong proponents of the.Progressive campaign. ${ }^{41}$

Backers of the former vice-president were scattered throughout other state organizations as well. Some accounts of the $1948 \mathrm{NFU}$ convention testify to the presence of strong third party sentiments among the delegates. ${ }^{42}$ But none of the large state organizations was publicly identified in the Wallace camp. Iowa and the Eastern Division were among the smaller state units, and their leadership, along with that in Minnesota, was less cautious than that in the national office, North Dakota, or the GTA. ${ }^{43}$

Ultimately, the "political realities" of American liberalism account for the failure of Patton and the Farmers Union to back Wallace in 1948. Although they worried about the prospects of a Republican president, FU leaders probably were more concerned about the continuation of GOP control of Congress. The Eightieth Congress had given them fits, and the Wallace candidacy threatened to erode electoral support for liberal Democrats, many of whom were proven friends of the Farmers Union. Truman's appointment of Brannan, of course, was a shrewd political move and did much to reconcile Patton and other FU figures to the incumbent administration. Now, a Truman defeat would also mean the departure of a friendly secretary of agriculture, the first since Wallace himself, who had left the post in

40. MacDougall, Gideon's Army.

41. Eastern Union Farmer, February 1948.

42. The Farm Journal 72 (April 1948), 35, claimed that "the [Farmers Union] leadership plugged hard for Henry Wallace," but "he was not endorsed." This publication was a critic of the NFU and earlier had been sued unsuccessfully by a New York FU leader. Lee Fryer told Baldwin that "a straw ballot of the convention delegates ... would undoubtedly have shown a vote of about $75 \%$ for Henry Wallace." No such poll was taken, however, because of the likelihood "the convention would have split wide open, and we would have come out of it with a much narrower Farmers Union." Fryer to Baldwin, 27 March 1948, Talbott Family Papers.

43. Iowa and the Eastern Division had 1,712 and 964 family memberships respectively, while the totals for North and South Dakota were 33,198 and 11,395 in 1948. Membership figures, box 22, folder 4, National Farmers Union Papers, University of Colorado, Boulder, Colorado. 
early 1940 to run for vice-president. The increasing antiCommunist hysteria that was sweeping the nation also may have inhibited Patton and others. Communists and their allies were open backers of the Wallace effort, making it easier to characterize it as a "Communist front." Had Patton and the FU opted for the Progressive cause they would have opened themselves up for further attack and risked large membership losses. As it was, the Farmers Union in many communities was subjected to scurrilous attacks as a "red" organization, and the Union's leadership was acutely aware of that threat.

WALLACE'S FAILURE to attract more rural voters to his cause was not, however, due solely to such "political realities." The Wallace campaign's neglect of the farm issue may have diminished the appeal of the third party effort in the countryside. In late May 1948 the former New Deal secretary of agriculture admitted his neglect of the farm issue. "Thus far," he said, "I've been concentrating my campaign efforts on the urban areas. I've been relying on the fact that I'm pretty well known in the rural districts to help me."44 Despite prodding from some backers, Wallace continued his neglect of the farm issue throughout the remainder of the campaign. The big issues that year were foreign policy and civil rights. One sympathetic observer later noted, "the goal was as big a vote as possible, and the best way to attain it was perceived to be the major urban areas." 45

The campaign appointed a farm director in the late summer of 1948 , but paid little attention to his ideas. He was Homer Ayres, a South Dakota sheep rancher who had participated in the rural revolt of the 1930s and in the Farmers Union, and most recently served as the farm-labor director of the Farm Equipment Workers (CIO). His responsibilities included arranging a September farm conference in Chicago and writing farm materials for the campaign. He later noted that his colleagues in the na-

44. Sam Lusky, "Wallace Pauses Here, Picks Two Favorite Foes," Rocky Mountain News, 28 May 1948.

45. Max Gordon to author, 1 March 1973. Gordon, at the time of the Wallace campaign, was a staff writer for the Daily Worker and often wrote on farm issues. 
tional office "pushed the farm stuff to one side," as few there knew much or "gave a damn about farmers. ${ }^{\text {"46 }}$

The Chicago farm meeting was held in September and attracted approximately thirty delegates. Wallace, Elmer Benson, Fred Stover, and Eastern Division FU president Ed Yeomans were among its participants. It covered a wide range of farm topics, and Wallace reportedly "told C. B. Baldwin he learned more about the farm problem those two days than he ever knew in his life." This same source, however, also remembers that Wallace kept dropping off to sleep during the sessions. ${ }^{47}$

Following the Progressive Farm Conference, some of the farm activists felt that their candidate would then address the farm issue. Their hopes were unjustified, however; Wallace made only one publicized farm speech in the campaign. It came at Moorhead, Minnesota, in October, and received little publicity. Whether or not more attention to agricultural matters would have significantly enhanced Wallace's vote in rural areas, the failure even to try reflected the urban bias of the campaign managers. No matter what Wallace said or did, he would not have gained the public backing of Patton or Thatcher. On the other hand, a frontal assault on the Administration's farm policy, coupled with a forceful presentation of the Progressive farm plank, may have recruited more FU members to the Progressive banner. Stover, Benson, Ayres, and others had tried to raise the farm issue in the campaign, but their efforts were undercut by their standard bearer and his managers. ${ }^{48}$ It was an old story in Amer-

46. Homer Ayres to author, 12 January 1973, February 1973 (cassette).

47. Ibid.; New York Times, 16 September 1948 clipping; "Report of the Progressive Party Farm Conference," Fred W. Stover Papers, Hampton, Iowa. (This and other materials cited from this collection loaned to the author.)

48. Ayres to Stover, 21 [September 1948], Stover Papers; MacDougall, Gideon's Army, 606. Stover later was very critical of Wallace's neglect of the farm issue during the campaign, though he never thought that the candidate should stress agriculture over foreign policy. When the Iowa farm leader accepted the assignment of nominating Wallace, he wrote, "My own thinking is that the thing that should be stressed and pointed up above all else [in the nominating speech] is his position on the war and peace issue. Certainly his splendid record with regard to agriculture should be mentioned, but I don't think it should be the main thing." Stover to Baldwin, 6 July 1948, Stover Papers. Republican farm spokesmen had a similar problem with their candidate in regard to neglecting agriculture. See James L. Forsythe, "Postmortem on the Election of 1948: An Evaluation of Cong. Clifford R. Hope's Views," Kansas Historical Quarterly 38 (Autumn 1972), 338-59. 
ican history that urban radicals often had neglected their rural counterparts, but this time such neglect was aided and abetted by the nation's best-known secretary of agriculture.

Despite his neglect of the farm issue, Wallace did better in some rural areas than almost anywhere else but New York City and Los Angeles. This result has received little attention. Curtis MacDougall asserts that Wallace's "vote in rural areas was negligible," and other observers have shared his assessment. ${ }^{49}$ But North Dakota, perhaps the nation's most rural state, gave the Progressive candidate close to 4 percent of its presidential vote. On a percentage basis, this was Wallace's third-best showing. ${ }^{50}$ That North Dakota was a strong Farmers Union state and heir to an extended history of agrarian insurgency may explain this result. ${ }^{51}$ Wallace's best performance there came in Williams and Mountrail counties, where he drew 13 and 10.8 percent of the vote respectively. These were strong Farmers Union counties: Williams County possessed more FU members than any other county in the state; and both counties earlier had a strong Socialist and Nonpartisan League presence, and during the 1930s were centers of farm protest..$^{52}$

49. MacDougall, Gideon's Army, 604; Samuel Lubell, The Future of American Politics (New York, 1965). I do not mean to suggest that Wallace received more votes in rural areas than he did in cities. But in some rural districts, his percentage of the vote was higher than that recorded in many urban districts.

50. MacDougall, Gideon's Army, vol. 3, inside cover.

51. Later, the Democratic national committeeman from North Dakota attributed Truman's loss of his state in 1948 to "the Farmers Union and nonpartisan league [being] 'Off the Reservation' with Henry Wallace." D. G. Kelly to Truman, 21 October 1952, box 1, David G. Kelly Papers, University of North Dakota, Grand Forks, North Dakota. It was an exaggeration, but he did have some basis for making the comment. Foreign policy, however, probably played a more important role than the farm issue in the Wallace vote there. See Robert P. Wilkins, "The Non-Ethnic Roots of North Dakota Isolationism," Nebraska History 44 (September 1963), 205-21. Wilkins does not treat the Wallace campaign, but his discussion has relevance to this topic.

52. Compilation of Election Returns: National and State, 1946-1964 [Bismarck, N.D., 1965]. Wallace carried five precincts in each county. Williston Herald, 3 November 1948; Mountrail County Promoter, 25 November 1948. Samuel Lubell, Future of American Politics, 197-98, claimed that the former vice-president only won "thirty precincts in the whole country," but he overlooked ten more of them in these two counties alone. Williams County elected a Socialist sheriff three times between 1912 and 1916, and Mountrail gave the Socialist Congressional candidate 45 percent of the vote in 1912. North Dakota Blue Book 1913 (Bismarck, 1913), 262-64. 
Wallace attracted rural voters in other outposts of agrarian insurgency in the Upper Midwest. ${ }^{53} \mathrm{~A}$. W. Ricker, now retired on his Iowa farm after a half-century of involvement in regional agrarian movements, had been impressed with the Progressive platform and told Patton, "Any good Farmers Union man who cares to do so can take that farm program of the Progressives and make it very embarrassing to Farmers Union members who refrain from supporting Wallace in his campaign." 54 Perhaps more farmers would have agreed with these sentiments if Wallace had addressed the farm issue more aggressively, or if the FU leadership had been more openly sympathetic to his cause.

But other factors were at work as well. Quentin Burdick, a strong Wallace backer in 1948, wrote in early 1955, "It is my opinion, that Wallace would have received a much greater vote, in fact a huge vote in North Dakota, but for one thing. The farmers were afraid they might lose their farm program . . . and voted for Truman [,] believing Wallace had no chance of winning. To many Wallace was their choice but [at] the last minute they voted for Truman. ${ }^{\prime 55}$ His explanation for Wallace's less-than-expected

53. In Roberts County, South Dakota, for example, Wallace attracted a significant vote in precincts that earlier had backed farmer-labor candidates and were centers of farm protest in the 1930s. There, four precincts gave close to 32 percent of their vote to the state secretary of the Communist party when he ran for Congress in 1934. Wallace attracted almost 13 percent of their vote in 1948, and one precinct gave him just under 19 percent of its vote. Official Canvass of the General Election in Roberts County, S.D., 6 November 1934, and 2 November 1948, Roberts County Court House, Sisseton, South Dakota.

54. Ricker to Patton, 26 July 1948, Patton Papers. Theodore Saloutos described Ricker as "an ex-Producers' Alliance man, ex-Nonpartisan Leaguer, ex-Socialist, ex-Populist, and ex-Farmers' Alliance man." Theodore Saloutos and John D. Hicks, Twentieth Century Populism: Agricultural Discontent in the Middle West, 1900-1939 (Lincoln, NE, n.d.), 235. Ricker apparently backed Wallace. Ironically, he himself earlier had been critical of Patton's popular front stance. In 1947 his correspondence with the NFU leader reveals strong anti-Communist sentiments. Ricker was critical of Communists in the United States rather than the Soviet Union. See Ricker to Patton, 17 and 26 September 1947, Patton Papers.

55. Burdick to Curtis D. MacDougall, 25 January 1955, box 38, file 77, Progressive Party Papers. Burdick later was elected to the U.S. Senate as a Democrat and, as of this date, has served four consecutive terms. Two other Northern Plains senators also had the 1948 Progressive campaign in their background. South Dakota's George McGovern was a Wallace supporter at least as late as the summer of 1948, and Kent Conrad, North Dakota's other current senator, is the son of Gaylord Conrad, who was selected as a delegate to the Wallace convention, but did not attend. 
vote in North Dakota has application beyond that state and the 1948 Progressive campaign. To be sure, North Dakota voters had a history of political nonconformity. There, too, however, many of them opted for "the lesser evil," fearing that things would be worse under a Republican president. Perhaps a strong Wallace pitch, denouncing the sins of the Truman Administration, particularly on the farm front, would have helped Wallace's cause. ${ }^{56}$ On the other hand, potential backers in North Dakota and elsewhere knew that he would not be elected and often were susceptible to the plea not to waste their vote. Third party campaigns in the United States normally had to swim upstream against a strong current. ${ }^{57}$ In 1948, for a variety of reasons, Farmers Union figures like Patton, Thatcher, and Talbott opted not to fight that battle, and they celebrated Truman's surprising victory as their own. ${ }^{58}$

Some liberal organizations used Truman's foreign policy and the Wallace campaign as a litmus test for their officials. In the CIO, for example, "left" unions were expelled in part for their opposition to the Marshall Plan and their support of Wallace's candidacy. ${ }^{59}$ Here and elsewhere, this apostasy was interpreted as a sign of disloyalty and grounds for excommunication. The NFU, however, held no such inquisition at the time. When the Truman Administration called for a new approach to farm ques-

56. One third party functionary suggested that Wallace's failure to campaign may have helped his vote in some places. "Barney Conal surmises that by not campaigning harder, especially in the Rocky Mountain states, less antagonism and counterattack were generated in those places." MacDougall, Gideon's Army, 770.

57. A classic study of third parties is John D. Hicks, "The Third Party Tradition in American Politics," Mississippi Valley Historical Review 20 (June 1933), 3-28.

58. Patton told the Minnesota Farmers Union convention after the election, "Thank God for Truman's election. I shall never, never, and I have never and I don't see how I ever could lose faith in the American people after what happened on November 2." Livermore, "James G. Patton," 150. Lee Fryer sent a curious letter to the National Guardian, a popular front weekly established during the Wallace campaign. He seemed delighted with Truman's victory and quoted Patton, "over a night-cap," as saying, "this will show again that people are fundamentally progressive. They'll always kick over the propaganda machine if they have a chance." National Guardian, 8 November 1948.

59. See Cochran, Labor and Communism, 297-315; Harvey A. Levenstein, Communism, Anticommunism, and the CIO (Westport, CT, 1981), 298-307. 
tions with the Brannan Plan, the Farmers Union went all out for it. Still troubled by the Cold War posturing, Patton, Talbott, and others continued to criticize Truman's foreign policy and openly opposed NATO when it was proposed. ${ }^{60}$ In this respect, the Farmers Union differed from many mainstream liberal organizations. It had weathered the Wallace candidacy with little dissension, and what divisions existed seemingly were papered over with a common commitment to Fair Deal measures at home and criticism of major Truman policies overseas. ${ }^{61}$

Not until the fighting in Korea began did the NFU undergo internal turmoil akin to that which earlier had disrupted the ranks of organized labor. Then, Patton and the NFU endorsed Truman's foreign policy, including U.S. involvement in Korea, and took steps to disassociate themselves from left-wing critics of the Administration. Henry Wallace himself quickly announced support of U.S. policy in Korea. But some of his earlier supporters in the NFU, such as Fred Stover and key figures in the Eastern Division, remained in opposition and ultimately were purged by the nation's only liberal farm organization. ${ }^{62}$

The 1948 Wallace campaign was a watershed for the left, but it was not a major turning point for the Farmers Union. That came later, when its leadership decided that there was no place

60. Crampton, National Farmers Union, 217, writes, "At the time the Korean War broke out, the Union had an official record of opposition to the major programs of the Truman foreign policy." This comment is an exaggeration. The NFU was not officially opposed to the Marshall Plan, though some state units such as Minnesota had openly rejected it. At the state level, the "red" issue did surface prior to the Korean fighting: the Wisconsin organization removed two employees from the state office in early 1948; South Dakota terminated two or three fieldmen in early 1949 reportedly over this question; and Einar Kuivinen was defeated for reelection as Minnesota president in late 1949 at least in part because of his popular front stance, a step that led to other individuals also losing their jobs with the state FU. The national organization, however, did not participate in such efforts and refused to adopt a membership prohibition against Communists. This information is based on unpublished research by the author.

61. "[T]he Patton-Thatcher-Talbot[t] forces leaned over at the [1950 NFU] convention to embrace the left in order that they might show a strong unified front to the Administration. They worked to keep any anti-red resolutions off the floor." Bob Coe to Jimmy Youngdale, 15 March 1950, Elmer A. Benson Papers, Minnesota Historical Society, St. Paul, Minnesota.

62. For a brief discussion of this topic, see Dyson, Red Harvest, 197-99; and Pratt, "Glenn J. Talbott, the Farmers Union, and American Liberalism after World War II." 
The AnNals of Iowa

in its organization for affiliates that opposed Truman's foreign policy from the left. By that time, however, the remnants of the popular front were in complete disarray, and the Cold War mentality had an iron-clad grip on American liberalism. 
Copyright of Annals of Iowa is the property of State of Iowa, by \& through the State Historical Society of Iowa and its content may not be copied or emailed to multiple sites or posted to a listserv without the copyright holder's express written permission. However, users may print, download, or email articles for individual use. 